\title{
Glutathione-s-transferase is a minor allergen in birch pollen because of restricted release from hydrated pollen grains
}

\author{
Stephan Deifl ${ }^{1 *}$, Christian Zwicker ${ }^{1}$, Eva Vejvar ${ }^{2}$, Claudia Kitzmüller ${ }^{1}$, Gabriele Gadermaier $^{2}$, Birgit Nagl ${ }^{1}$, \\ Susanne Vrtala ${ }^{1}$, Gerhard Zlabinger ${ }^{3}$, Peter Briza ${ }^{2}$, Fatima Ferreira ${ }^{2}$, Barbara Bohle ${ }^{1}$ \\ From 5th International Symposium on Molecular Allergology (ISMA 2013) \\ Vienna, Austria. 6-7 December 2013
}

\section{Background}

Recently, proteomic profiling of birch pollen detected a protein homologous to glutathione-S-transferases (GST) in prominent amounts. In mites, cockroach and fungi, GST are relevant allergens. This tempted us to investigate the allergenicity of GST from birch (bGST).

\section{Methods}

bGST was expressed in Escherichia coli, purified and characterized by mass spectrometry. BALB/c mice were immunized with bGST or Bet v 1 . Antibody and T cell responses were assessed. 217 sera from birch pollen-allergic patients were tested for IgE-reactivity to bGST by ELISA. The allergenicity of bGST was evaluated with IgE-loaded rat basophil leukaemia cells (RBL) expressing the $\alpha$-chain of the human receptor FceRI. Cross-reactivity of IgE between bGST and GST from house dust mite, Der p 8, was assessed with murine and human sera in ELISA. The release kinetics of bGST and Bet $\mathrm{v} 1$ from birch pollen upon hydration were studied by immunoblotting.

\section{Results}

Immunization with bGST induced specific IgE and a Th2-dominated cellular immune response comparably to immunization with Bet $\mathrm{v} 1$. Only $13.4 \%$ of birch pollen-allergic patients were sensitized to bGST. In RBL assays bGST induced mediator release. GST from birch and house dust mites did not cross-react. In contrast to Bet v 1, bGST showed a limited and delayed release from hydrated birch pollen grains.

'Medical University of Vienna, Department of Pathophysiology and Allergy Research, Vienna, Austria

Full list of author information is available at the end of the article

\section{Conclusion}

bGST induces specific IgE in mice but is of limited sensitizing capacity for humans. In contrast to Bet $\mathrm{v} 1$, the release of bGST from hydrated pollen is restricted. Thus, the minor allergenicity of bGST may be explained by a limited exposure of patients to this protein.

\section{Authors' details}

'Medical University of Vienna, Department of Pathophysiology and Allergy Research, Vienna, Austria. ${ }^{2}$ University of Salzburg, Department of Molecular Biology, Salzburg, Austria. ${ }^{3}$ Medical University of Vienna, Institute of Immunology, Vienna, Austria.

Published: 17 March 2014

doi:10.1186/2045-7022-4-S2-01

Cite this article as: Deifl et al:: Glutathione-s-transferase is a minor allergen in birch pollen because of restricted release from hydrated pollen grains. Clinical and Translational Allergy 2014 4(Suppl 2):O1.

Submit your next manuscript to BioMed Central and take full advantage of:

- Convenient online submission

- Thorough peer review

- No space constraints or color figure charges

- Immediate publication on acceptance

- Inclusion in PubMed, CAS, Scopus and Google Scholar

- Research which is freely available for redistribution

Submit your manuscript at www.biomedcentral.com/submit 